\title{
KOHESI GRAMATIKAL DALAM NOVEL SANG PEMIMPI KARYA ANDREA HIRATA
}

\author{
Sumiharti $^{1}$, Mia Ismawati ${ }^{2}$ \\ Program Studi Pendidikan Bahasa dan Sastra Indonesia, Fakultas Keguruan dan \\ Ilmu Pendidikan, Universitas Batanghari, \\ Jambi \\ harti.sumi@yahoo.com
}

\begin{abstract}
This research aims at describing the type of conjunction grammatical cohesion in Andrea Hirata's novel Sang Pemimpi. This type of grammatical cohesion consists of grammatical cohesion of reference and grammatical cohesion of substitution. This research is a qualitative descriptive. Qualitative descriptive research is a way to solve problems in research by describing and interpreting objects in the form of symptoms or social events in life according to the original data. In this research, the sources of the data are words, sentences, quotes, or expressions found in the dialogues of the characters in Andrea Hirata's novel Sang Pemimpi. Based on the results of the research it can be concluded that there are types conjunction grammatical cohesion found in the novel Sang Pemimpi by Andrea Hirata. The most dominant type is anaphora endophora reference grammatical cohesion, while the least type occured is grammatical cohesion of anaphora endophora substitution. There are 130 utterances of reference grammatical cohesion found in the novel, consisting of 122 anaphora endophora and 8 cataphora endophora. There are 7 substitution grammatical cohesion of anaphora endophora.
\end{abstract}

Keywords: grammatical cohesion, novel, Sang Pemimpi

\footnotetext{
${ }^{1}$ Dosen Program Studi Pendidikan Bahasa dan Sastra Indonesia, Fakultas Keguruan dan Ilmu Pendidikan, Universitas Batanghari, Jambi

${ }^{2}$ Mahasiswa Program Studi Pendidikan Bahasa dan Sastra Indonesia, Fakultas Keguruan dan Ilmu Pendidikan, Universitas Batanghari, Jambi
} 


\section{PENDAHULUAN}

Bahasa memegang peran penting dalam kehidupan, sebagai alat menyampaikan pikiran, gagasan, konsep ataupun perasaan, karena pada umumnya bahasa digunakan untuk berkomunikasi. Rofii dan Hasibuan (2019) mengatakan bahwa fungsi bahasa yang paling mendasar ialah sebagai alat komunikasi. Bahasa digunakan masyarakat sebagai alat pergaulan antarsesama dan alat untuk menyampaikan hasil pemikiran. "Bahasa adalah suatu sistem lambang berupa bunyi, bersifat arbiter. Bahasa digunakan oleh satu masyarakat tutur untuk bekerja sama, berkomunikasi, dan mengidentifikasi diri" (Chaer, 1998:1). Hal itu menunjukkan bahwa bahasa merupakan alat komunikasi sosial yang memiliki peranan penting bagi manusia. Bahasa juga menjadi kekuatan dan sumber kehidupan sebagai cerminan penuturnya dalam masyarakat. Oleh karena itu, bahasa harus bisa dipahami orang lain.

Bahasa seseorang sangat ditentukan dari bagaimana cara manusia berkomunikasi kepada orang lain. Dengan berbahasa yang baik, komunikasi akan berjalan dengan lancar. Terkadang orang berbahasa bisa dinilai dari kata-kata yang diucapkannya apakah lawan bicaranya paham dan mengerti apa maksud yang ingin diutarakan oleh orang tersebut.

Bahasa dan penggunaanya mencakup aktivitas manusia secara keseluruhan, baik yang bersifat ilmiah maupun yang nonilmiah dalam wacana sehari-hari. Dari definisi tersebut dapat dikatakan bahwa dengan bahasa manusia dapat berkomunikasi dengan sesama. Bahasa mempunyai peranan yang sangat penting dalam tindak komunikasi, baik komunikasi yang berupa lisan maupun tulisan. Seseang dikatakan berbahasa bila mampu menggunakan bahasa tersebut. Dengan demikian dapat dikatakan kecakapan berbahasa seseorang dapat dilihat dari kemampuan seseorang dalam berbahasa baik secara lisan maupun tulisan.

Dengan bahasa, manusia dapat mengkomunikasikan perasaan, pikiran dan kemampuannya kepada orang lain. Bahasa tidak hanya digunakan sebagai alat komunikasi, tetapi juga sebagai media yang akan membawa anak ke tingkat pendidikan yang lebih optimal dalam proses pembelajaran. Berbahasa pada dasarnya adalah proses interaktif komunikatif yang menekankan pada aspek-aspek berbahasa. Kemampuan memahami aspek-aspek tersebut sangat menentukan keberhasilan dalam proses komunikasi.

Kesatuan bahasa yang lengkap bukanlah kata atau kalimat melainkan wacana. Sebagai alat komunikasi, bahasa terdiri dari kalimat yang saling berkaitan. Bahasa berkaitan erat dengan wacana. Wacana dapat menjadi objek peluapan emosi dan dapat juga sebagai gambaran dari penulis itu sendiri.

Wacana merupakan suatu unit bahasa yang lebih besar dari pada kalimat atau rangkaian yang bersinambungan dari bahasa, yang lebih besar dari pada kalimat. Wacana terdiri dari dua bagian yaitu, wacana lisan dan tulisan. Wacana lisan ditemukan dalam percakapan, pidato, dan lelucon, sedangkan wacana tulis terutama pada media menggunakan bahasa tulis.

Sebuah wacana tulis dikatakan baik apabila hubungan antar kalimatkalimatnya kohesif dan koheren. Kohesif merujuk pada bentuk, artinya kalimat kalimat yang mem-bangun paragraf itu haruslah berhubungan secara padu. Koheren merujuk pada kepaduan gagasan antar bagian dalam wacana. Kalimat sebagai bagian dari wacana memerlukan penanda kohesi yang tidak hanya sebagai alat penghubung unit struktur, 
tetapi juga berfungsi semantic. Oleh karena itu, kepaduan kalimat-kalimat dalam sebuah wacana tulis dapat dianalisis dari unsur penanda kohesi yang digunakan. (Pernando. E dan Ade Rahima (2017:2). Berdasarkan pendapat ini, dapat disimpulkan bahwa penanda kohesi memegang peranan yang sangat penting dalam pemahaman sebuah wacana.

Selanjutnya berkaitan dengan hal tersebut, mengutip dari Purwoko (2008) Pernando dan Ade Rahima (2017:3) menjelaskan bahwa kohesi dapat dibedakan menjadi 2 jenis yakni,kohesi yang bersifat gramatikal (grammatical cohesion) dan kohesi yang bersifat leksikal (lexical cohesion). Untuk menciptakan kohesi, baik kohesi gramatikal maupun kohesi leksikal, digunakan sebuah alat yang disebut penanda kohesi. Dengan penandapenanda kohesi tersebut, baik leksikal maupun gramatikal, penutur atau penulis akan lebih mudah menyampaikan ide atau amanat yang ingin disampaikan melalui sebuah wacana. Selain itu, ide atau amanat yang hendak disampaikan tersebut akan mudah diterima atau dipahami oleh mitra tutur atau pembaca.

Menurut Holliday dan Hasan (dalam Zaimar dan Harahap, 2011 :115) "Kohesi adalah suatu konsep semantik yang menampilkan hubungan makna antar unsur teks, dan menyebabkannya dapat disebut sebagai teks. Kohesi terjadi apabila interpretasi salah satu unsur teks tergantung dari unsur lainnya. Unsur yang satu berkaitan dengan unsur Iainnya, sehingga unsur tersebut tidak dapat benar-benar dipahami tanpa yang lain. Kaitan makna ini disebut kohesi salah satunya kohesi gramatikal.

Menurut Holliday dan Hasan (dalam Zaimar dan Harahap, 2011 :117) "kohesi gramatikal dapat diklasifikasikan dalam beberapa kategori, yaitu: referensi (pengacuan), substitusi (penyulihan), elipsis (pelepasan), dan konjungsi (penyambungan).

Selanjutnya, Menurut Cook (1989: 21) "Konjungsi adalah hubungan yang ekplisit antara satu kalimat atau satu klausa dengan yang lainnya". Kridalaksana (dalam Arifin, 2010:36) berpendapat bahwa konjungsi atau kata sambung adalah bentuk atau satuan kebahasaan yang berfungsi untuk menyambung, merangkai atau menghubungkan kata dengan kata, frasa dengan frasa, klausa dengan klausa, kalimat dengan kalimat dan seterusnya. Penyambungan (konjungsi) sebagai alat kohesi, juga berkaitan dengan aspek semantik, biasanya terdapat dalam karya sastra.

Karya sastra merupakan sebuah ciptaan hasil kreativitas seorang penyair dalam mengungkapkan perasaan. Melalui karya sastra, masyarakat khusunya para penikmat karya sastra dapat mengetahui lebih banyak mengenai kehidupan manusia maupun kehidupan alam semesta. Suatu karya sastra dapat memperkaya wawasan pembaca dengan berbagai sudut pandang seperti psikologi, sejarah, sosial, politik, dan antropologi. Karya sastra sendiri terbagi atas beberapa jenis, di antaranya prosa, puisi, dan drama. Dari ketiga jenis karya sastra tersebut secara keseluruhan menggunakan bahasa dalam pembuatannya. Maka, dapat disimpulkan bahwa karya sastra merupakan gambaran dunia dan kehidupan manusia kemudian hasilnya itu dituangkan ke dalam sebuah karya tulis yang indah dari bentuk, isi, maupun bahasanya sehingga para pembaca dapat menikmati sebuah karya sastra.

Salah satu karya sastra yang populer yang memuat ketentuan bahasa secara utuh adalah novel. Novel adalah sebuah prosa yang mengisahkan atau menceritakan kisah seorang atau 
beberapa tokoh dalam ratusan halaman. Dalam sebuah novel pengarang selalu memaparkan tokoh dalam bentuk bahasa tulisnya. Tokoh-tokoh tersebut di jelaskan secara langsung baik itu sifat, watak dan prilaku melalui kutipankutipan di dalamnya. Kutipan di dalam novel hendaknya memenuhi penulisan bahasa Indonesia yang baik dan benar, sesuai dengan Pedoman Umum Ejaan Bahasa Indonesia (Puebi).

Novel merupakan sebuah cerita karangan prosa yang panjang yang mengandung serangkaian cerita kehidupan yang berusaha menggambarkan atau melukiskan kehidupan tokoh-tokohnya dengan berbagai unsur yang mendukungnya supaya dapat menonjolkan watak dan sifat pelakunya. Seluk beluk yang terjadi dalam cerita novel tidak hanya sebagai suatu cerita khayalan semata melainkan juga sebuah imajinasi yang dihasilkan oleh pengarang.

Novel Sang Pemimpi terbit pada tahun 2006 yang ditulis oleh Andrea Hirata. Novel ini menceritakan tentang kehidupan masa SMA sang penulis di Belitong, di dalam novel ini terdapat tiga tokoh utama yakni, Ikal (Andrea Hirata), Arai dan Jimbron. Novel Sang Pemimpi ini menceritakan kisah persahabatan dari ketiga tokoh utama tersebut dari masa kecil hingga lulus SMA. Andrea Hirata merupakan penulis yang lahir di Gantung, Belitung Timur, Bangka Belitung pria berusia 51 tahun ini lahir pada 24 Oktober 1967. Novel pertamanya menghasil-kan tiga sikuel. Andrea Hirata bukanlah penulis yang dapat diremehkan ini dibuktikan dengan beberapa novel nya yang difilmkan, seperti Laskar Pelangi dan Sang Pemimpi. film Laskar Pelangidi produksi oleh Mills Films dan Mizan Production pada tahun 2008. Film Sang Pemimpi juga di produksi oleh Mills
Films dan Mizan Production pada tahun 2009.

Berdasarkan beberapa uraian di atas, penelitian tentang jenis kohesi gramatikal konjungsi pada novel Sang Pemimpi karya Andrea Hirata ini penting untuk dilakukan

Berdasarkan latar belakang yang telah diuraikan, maka dapat diidentifikasi masalah yaitu bagaimana jenis kohesi gramatikal konjungsi pada novel Sang Pemimpi karya Andrea Hirata, menurut Holliday dan Hasan (dalam Kusuma, 2011:121) kohesi gramatikal dapat diklafikasikan dalam beberapa kategori, yaitu referensi (pengacuan), substitusi (penyulihan), elipsis (pelepasan), dan konjungsi (penyambung).

Adapun fokus permasalahan dalam penelitian ini yaitu bagaimana jenis kohesi gramatikal konjungsi referensi (pengacuan) dan substitusi (penyulihan) dalam Novel Sang Pemimpi karya Andrea Hirata.

Berdasarkan fokus permasalahan, maka pertanyaan penelitian ini sebagai berikut.

1. Bagaimanakah jenis kohesi gramatikal referensi (pengacuan) dalam Novel Sang Pemimpi Karya Andrea Hirata?

2. Bagaimanakah jenis kohesi gramatikal substitusi (penyulihan) dalam Novel Sang Pemimpi Karya Andrea Hirata?

Berdasarkan fokus dan pertanmyaan penelitian yang telah dipaparkan maka tujuan penelitian ini sebagai berikut.

1. Mendeskripsikan jenis kohes gramatikal referensi (pengacuan) dalam Novel Sang Pemimpi Karya Andrea Hirata.

2. Mendeskripsikan jenis kohesi gramatikal substitusi (penyulihan) dalam Novel Sang Pemimpi Karya Andrea Hirata. 
Adapun beberapa manfaat teoretis dari penelitian ini sebagai berikut.

1. Dapat menambah wawasan atau pengatahuan tentang makna serta penggunaan kohesi gramatikal konjungsi dalam ilmu kebahasaan.

2. Penelitian ini juga bermanfaat untuk memberikan penjelasan secara teoretis yang berkaitan dengan masalah penelitian.

Selanjutnya manfaat praktis dari penelitian ini adalah sebagai berikut.

1. Bagi guru, hasil penelitian ini dapat dijadikan bahan acuan dalam pengembangan materi pembelajaran bahasa Indonesia di sekolah.

2. Bagi siswa, hasil penelitian ini dapat menambah pengetahuan serta pemahaman mengenai jenis serta penggunaan kohesi.

3. Bagi calon guru, hasil penelitian ini dapat menambah dan memperkaya pengetahuan serta wawasan dalam tata kebahasaan Indonesia terutama jenis konjungsi gramatikal sehingga kelak dapat menyampaikannya kepada siswa secara lebih baik.

4. Bagi peneliti lain, hasil penelitian ini dapat menjadi bahan perbandingan dalam penelitian yang sejenis khususnya penelitian tentang kohesi gramatikal konjungsi.

\section{METODE PENELITIAN}

"Jenis penelitian berarti cara yang digunakan seseorang peneliti di dalam usaha memecahkan masalah yang diteliti" (Siswantoro, 2010 : 55). Jenis penelitian yang ini adalah deskriptif kualitatif. "Deskriptif adalah prosedur pemecahan masalah yang diselidiki dengan menggambarkan atau melukiskan keadaan subjek atau objek penelitian (puisi) berdasarkan fakta-fakta yang tampak atau sebagaimana adanya" Nawawi (dalam Siswantoro, 2010: 56).
Penelitian kualitatif merupakan jenis penelitian yang lebih menekankan pada aspek pemahaman secara mendalam terhadap suatu masalah. "Penelitian kualitatif adalah penelitian yang digunakan untuk meneliti pada kondisi objek yang alamiah, di mana peneliti adalah sebagai instrument kunci, teknik pengumpulan data dilakukan, penelitian kualitatif lebih menekankan makna daripada generalisasi" (Sugiyono, 2016: 1). "Penelitian kualitatif dapat diartikan sebagai penelitian yang menghasilkan data deskriptif mengenai kata-kata lisan maupun tertulis, dan tingkah laku yang dapat diamati dari orang-orang yang diteliti" (Endraswara, 2013: 28). Pendekatan kualitatif digunakan dalam penelitian ini sebagai prosedur dalam memecahkan masalah yang sedang diteliti dengan cara mendeskripsikan atau menggambarkan data-data objek penelitian yang berhubungan dengan jenis kohesi gramatikal konjungsi dalam novel Sang Pemimpi karya Andrea Hirata.

Data merupakan unsur utama dalam penelitian yang disajikan sebagai bahan analisis. Menurut Ahmadi (2016: 19) "Data merupakan keteranganketerangan tentang suatu hal, dapat berupa sesuatu yang diketahui atau yang dianggap atau anggapan, atau suatu fakta-fakta yang digambarkan lewat angka, simbol, kode dan lain-lain”. Sumber data yang digunakan dalam penelitian ini adalah cerita dalam Novel Sang Pemimpi yang terbit pada tahun 2006 yang ditulis oleh Andrea Hirata.

"Teknik pengumpulan data merupakan bagian penting dari proses penelitian, begitu sentral peran pengumpulan data sehingga kualitas penelitian bergantungan padanya" (Siswantoro, 2010: 73). Pengumpulan data dalam penelitian ini menggunakan teknik dokumentasi dari studi literatur yang difokuskan untuk menganalisis 
jenis kohesi gramatikal konjungsi yang terdapat pada Novel Sang Pemimpi karya Andrea Hirata.

Teknik pengumpulan data dalam penelitian ini dilakukan dengan menggunakan langkah-langkah pendekatan struktural. Untuk lebih jelasnya dapat dilihat dalam penjelasan berikut.

1. Langkah pertama, membaca keseluruhan novel sumber terlebih dahulu. Dari pembacaan ini, diperoleh pengetahuan, kepekaan peneliti agar dapat menghayati dan memahami data secara mendalam dan kesan tentang novel tersebut.

2. Langkah kedua, membaca secara kritis, teliti dan berulang-ulang, tentang keseluruhan wacana dalam novel Sang Pemimpi karya Andrea Hirata.

3. Langkah ketiga, yang harus ditetapkan penelitian dalam melakukan analisis jenis kohesi gramatikal konjungsi yang terdapat pada Novel Sang Pemimpi karya Andrea Hirata. Dalam hubungan ini, peneliti juga dapat menetapkan aspek mana yang mau di teliti.

4. Langkah keempat, menganalisis data yang menyangkut jenis kohesi gramatikal konjungsi yang terdapat pada Novel Sang Pemimpi karya Andrea Hirata. serta, menandai setiap data tersebut dengan menggunakan stabilo yang menunjukkan jenis-jenis kohesi gramatikal konjungsi.

5. Langkah kelima, setelah data terkumpul, kemudian mengumpulkan data sesuai dengan jenis kohesi gramatikal konjungsi yang terdapat pada Novel Sang Pemimpi karya Andrea Hirata, aspek yang telah di temukan kemudian dimasukkan ke dalam tabel tabulasi.

\footnotetext{
"Teknik analisis data dilakukan dengan memaparkan dalam bentuk
}

deskriptif terhadap masing-masing data secara fungsional dan rasional" (Siswantoro, 2010:81). Teknik analisis data dalam penelitian ini dilakukan dengan pemaparan dalam bentuk katakata, kalimat, paragraf yang berhubungan dengan jenis kohesi gramarikal konjungsi dalam novel Sang Pemimpi karya Andrea Hirata.

Adapun tahapan yang dilakukan dalam analisis data adalah sebagai berikut.

1. Data yang telah terkumpul pada pengumpulan data, kemudian dimasukkan ke dalam tabel analisis.

2. Menganalisis data yang ada pada tiap tabel analisis data dan disesuikan dengan pendapat yang dikemukakan oleh Kusuma (2011:121-128).

3. Teknik pemeriksaan keabsahan data dilakukan dengan cara mencocokkan dengan teori jenis kohesi gramatikal konjungsi, keabsahan data dicocokan dengan teori metode penelitian sastra, melakukan kosultasi dengan dosen pembimbing.

4. Mendeskripsikan data yang telah dianalisis.

5. Merumuskan kesimpulan berdasarkan data yang telah dianalisis.

\section{HASIL DAN PEMBAHASAN}

Berdasarkan analisis data yang dilakukan, ditemukan jenis kohesi gramatikal referensi dan kohesi gramatikal substitusi dalam novel Sang Pemimpi karya Andrea Hirata sebanyak 137 kutipan.

1. Kohesi gramatikal referensi (pengacuan) yang ditemukan dalam novel Sang Pemimpi karya Andrea Hirata sebanyak 130 kutipan, terdiri atas kohesi gramatikal referensi endofora anafora sebanyak 122 kutipan; dan kohesi gramatikal referensi endofora katafora sebanyak 8 kutipan. 
2. Kohesi gramatikal substitusi (penyulihan) yang ditemukan dalam novel Sang Pemimpi karya Andrea Hirata sebanyak 7 kutipan, dan ketujuh kutipan tersebut merupakan kohesi gramatikal substitusi endofora anafora.

Jenis kohesi gramatikal konjungsi dalam novel Sang Pemimpi karya Andrea Hirata yang meliputi jenis kohesi gramatikal referensi dan kohesi gramatikal substitusi dijelaskan sebagai berikut.

\section{Kohesi Gramatikal Referensi}

Referensi menampilkan hubungan antara bahasa dan dunia. Dalam setiap bahasa, ada unsur-unsur bahasa yang tidak dipahami berdasarkan dirinya sendiri, melainkan merujuk (mengacu) pada hal lain pemahamannya. Informasi yang diberikannya tergantung pada hal lain. Referensi tekstual (endofora) digunakan dalam memahami hubungan yang diacu antarteks. Endofora dikenal dua macam rujukan, yaitu: anafora dan karafora. (Holliday dan Hasan dalam Kusuma, 2011: 121). Kohesi gramatikal referensi paling banyak ditemukan di dalam novel Sang Pemimpi karya Andrea Hirata, yakni sebanyak 130 kutipan. Berikut dipaparkan contoh-contoh kutipan kohesi gramatikal referensi berdasarkan endofora anafora dan endofora katafora.

\section{a. Kohesi Gramatikal Referensi Endofora \\ Anafora}

Hubungan anafora terjadi apabila unsur yang diacu terdapat sebelum unsur yang mengacu. Contohnya: Sita adalah mahasiswi di salah satu perguruan tinggi. Meskipun dia bukan anak yang pandai, nilainya selalu baik, karena selain rajin dan cantik, dia pandai bergaul. Teman-temannya selalu bersedia membantunya. (Holliday dan Hasan dalam Kusuma, 2011: 121). Berikut dipaparkan contoh-contoh dari kutipan kohesi gramatikal referensi endofora anafora.

\section{Kutipan 1 \\ Sebenarnya, Pak Mustar itu orang penting. Tanpa dia, kampung kami tak kan pernah punya SMA. Dia salah satu perintisnya. (SP:5)}

Pada kutipan 1 tersebut terdapat pronomina persona dia sebanyak dua kali yang terletak pada kalimat kedua dan ketiga. Semua pronomina persona tersebut mengacu pada tokoh Pak Mustar yang terdapat pada kalimat pertama (yang sedang dibicarakan dalam cerita). Hubungan tersebut merupakan perujukan endofora anafora. Jadi, dapat diketahui bahwa kalimat-kalimat tersebut memiliki keterkaitan yang padu satu sama lain. Kajian ini sesuai dengan teori yang dikemukakan oleh Holliday dan Hasan (dalam Kusuma, 2011: 12).

\section{Kutipan 2}

$\boldsymbol{A} \boldsymbol{k u}$ berjalan menuju pintu gudang diikuti Jimbron yang terpincangpincang. Tiba-tiba, kami terperanjat karena dentuman knalpot vespa Lambreta. Kami panik tak dapat menguasai diri (SP :10)

Pada kutipan 2 tersebut, terdapat pronomina Kami sebanyak dua kali kali yang terletak pada kalimat kedua dan ketiga. Semua pronomina tersebut mengacu pada tokoh Aku dan Jimbron yang terdapat pada kalimat pertama (yang sedang dibicarakan dalam cerita). Hubungan tersebut merupakan perujukan endofora anafora. Jadi, dapat 
diketahui bahwa kalimat-kalimat tersebut memiliki keterkaitan yang padu satu sama lain. Kajian ini sesuai dengan teori yang dikemukakan oleh Holliday dan Hasan (dalam Kusuma, 2011: 12).

\section{Kutipan 3}

Aku memutar gasing itu sekali, dan terperanjat sebab tiba-tiba ia berputar sendiri dengan keras sehingga kontruksinya bingkas, lidi-lidinya patah, dan buah-buah kenari itu berhamburan ke mukaku. (SP :22)

Pada kutipan 3 tersebut, terdapat pronomina $\boldsymbol{i} \boldsymbol{a}$ yang terletak pada klausa kedua, dan terdapat pronomina nya sebanyak dua kali, yaitu pada klausa kedua dan ketiga. Semua pronomina tersebut mengacu pada sebuah Gasing yang terdapat pada klausa pertama pada kalimat tersebut. Hubungan tersebut merupakan perujukan endofora anafora. Jadi, dapat diketahui bahwa klausaklausa tersebut memiliki keterkaitan yang padu satu sama lain. Kajian ini sesuai dengan pendapat yang dikemukakan oleh Holliday dan Hasan (dalam Kusuma, 2011: 12).

\section{Kutipan 4}

Yang bisa mengalahkan pamor dan wibawa A Pui hanya para penggawa masjid, yaitu Taikom Hakim, Haji Satar, dan Haji Hazani. Mereka adalah mesinmesin budi pekerti yang menganggap besi panas merupakan alat yang setimpal untuk meluruskan tabiat anakanak Melayu. Mereka sangat kejam. (SP :47)

Pada kutipan 4 tersebut terdapat pronomina mereka sebanyak dua kali yang terletak pada kalimat kedua dan ketiga. Semua pronomina tersebut mengacu pada para penggawa masjid, yaitu Taikom Hakim, Haji Satar, dan
Haji Hazani yang terdapat pada kalimat pertama (yang sedang dibicarakan dalam cerita). Hubungan tersebut merupakan perujukan endofora anafora. Jadi, dapat diketahui bahwa kalimat-kalimat tersebut memiliki keterkaitan yang padu satu sama lain. Kajian ini sesuai dengan teori yang dikemukakan oleh Holliday dan Hasan (dalam Kusuma, 2011: 12).

\section{b. Kohesi Gramatikal Referensi Endofora Katafora}

Hubungan katafora terjadi apabila unsur yang mengacu terdapat lebih dahulu dari unsur yang diacu. Contohnya: Dia selalu muncul dengan wajah yang lucu (1). Semua orang menyukainya (2). Setiap ada persoalan yang penting, teman-teman sekelas selalu meminta pertimbangannya (3). Selain lucu, ia memang bijaksana (4). Tak kusangka dia pergi secepat ini (5). Tabrakan telah merenggut nyawanya (6). Kami telah kehilangan Ikhsan, sahabat yang setia (7). (Holliday dan Hasan dalam Kusuma, 2011: 121). Berikut dipaparkan contoh-contoh dari kutipan kohesi gramatikal referensi endofora katafora tersebut.

\section{Kutipan 5}

Dia telah menerapkan sisir belah tengah seminggu sebelumnya dan tak sedikit pun kulihat nilai tambah pada wajahnya. Karena Arai diberkahi dengan bakat menghasut, aku termakan juga. (SP :28)

Pada kutipan 5 tersebut terdapat pronomina persona dia serta terdapat pronomina nya pada kalimat kedua. Semua pronomina tersebut mengacu pada tokoh Arai yang terdapat pada kalimat akhir (yang sedang dibicarakan dalam cerita). Hubungan tersebut merupakan perujukan endofora katafora. Jadi, dapat dilihat bahwa kalimatkalimat tersebut memiliki keterkaitan 
yang padu satu sama lain. Kajian ini sesuai dengan pendapat yang dikemukakan oleh Holliday dan Hasan (dalam Kusuma, 2011: 12).

Kutipan 6

Mulut mungilnya yang dari tadi berkicau terkunci, lau pelan-pelan menganga seperti ikan mas koki.

Dia tertegun saat pusaran kapas itu maju-mundur mendekatinya. Mata bulat bauh hamlam-nya bersinar-sinar seakan dia melihat sesosok malaikat yang besar dan bersayap melayang-layang ingin memeluknya. Mei Mei pucat pasi karena terpukau dalam ketakutan yang indah. (SP:41)

Pada kutipan 6 tersebut terdapat pronomina persona dia sebanyak dua kali pada kalimat ketiga dan keempat, dan terdapat pronomina nya sebanyak empat kali pada kalimat kedua, ketiga, dan keempat. Semua pronomina tersebut mengacu pada tokoh Mei Mei yang terdapat pada kalimat akhir (yang sedang dibicarakan dalam cerita). Hubungan tersebut merupakan perujukan endofora katafora. Jadi, dapat diketahui bahwa kalimat-kalimat tersebut memiliki keterkaitan yang padu satu sama lain. Kajian ini sesuai dengan teori yang dikemukakan oleh Holliday dan Hasan (dalam Kusuma, 2011: 12).

\section{Kutipan 7}

Dia ingin melanjutkan ceritanya, tapi kelelahan oleh gagapnya. Aku prihatin melihat mukanya. Polos, bersih seperti bayi. Kuduga Jimbron tak kan pernah tampak tua. (SP :51)

Pada kutipan 7 tersebut terdapat pronomina persona dia pada kalimat pertama, dan terdapat pronomina nya sebanyak 3 kali pada kalimat pertama dan kedua. Semua pronomina tersebut mengacu pada tokoh Jimbron yang terdapat pada kalimat terakhir (yang sedang dibicarakan dalam cerita). Hubungan tersebut merupakan perujukan endofora katafora. Jadi, dapat diketahui bahwa kalimat-kalimat tersebut memiliki keterkaitan yang padu satu sama lain. Kajian ini sesuai dengan teori yang dikemukakan oleh Holliday dan Hasan (dalam Kusuma, 2011: 12).

Kutipan 8

Kutipan Dia dipertotonkan pada ratusan santi dan dipaksa meringkik. Matanya yang lugu, tubuhnya yang gemuk, dan bahunya yang lungsur tampak lucu ketika tangannya menekuk di dadanya seperti bajing. Namun, bukannya malu, Jimbron malahan senang bukan main dengan hukuman itu. (SP :52)

Pada kutipan 8 tersebut terdapat pronomina persona dia pada kalimat kedua, dan terdapat pronomina nya sebanyak empat kali pada kalimat ketiga. Semua pronomina tersebut mengacu pada tokoh Jimbron yang terdapat pada kalimat akhir (yang sedang dibicarakan dalam cerita). Hubungan tersebut merupakan perujukan endofora katafora. Jadi, dapat diketahui bahwa kalimatkalimat tersebut memiliki keterkaitan yang padu satu sama lain. Kajian ini sesuai dengan teori yang dikemukakan oleh Holliday dan Hasan (dalam Kusuma, 2011: 12).

\section{Kohesi Gramatikal Substitusi}

Substitusi adalah penggantian unsur dalam teks oleh unsur lain. Seperti dalam referensi, dalam subsititusi juga dikenal sistem rujukan, meskipun terutama rujukan tekstual (endofora) saja baik berupa anafora maupun katafora. Hal ini mudah dipahami, karena substitusi adalah penyulihan (penggantian) suatu unsur bahasa oleh bahasa lainnya, jadi hanya 
ada dalam tataran bahasa. Dengan demikian, substitusi adalah hubungan antarunsur linguistik, misalnya hubungan antarkata, frase atau klausa. (Holliday dan Hasan dalam Kusuma, 2011: 121). Kohesi gramatikal substitusi hanya sedikit ditemukan di dalam novel Sang Pemimpi karya Andrea Hirata, yakni sebanyak 7 kutipan yang keseluruhannya merupakan substitusi endofora anafora.

\section{a. Kohesi Gramatikal Substitusi Endofora Anafora}

Hubungan anafora terjadi apabila unsur yang diacu terdapat sebelum unsur yang mengacu. Contoh substitusi hubungan anafora: di mana tanah tempat berpijak, di situ langit dijunjung. Itulah seharusnya pegangan kita bila berada di rantau orang. Pronomina penunjuk itu yang diikuti partikel lah merupakan bentuk linguistik yang merupakan substitusi dari kalimat yang telah ada sebelumnya, yaitu di mana tanah tempat berpijak, di situ langit dijunjung. Jadi, relasi antara dua unsur linguistik ini adalah hubungan anafora. (Holliday dan Hasan dalam Kusuma, 2011: 121). Berikut dipaparkan contohcontoh dari kutipan kohesi gramatikal substitusi endofora anafora.

Kutipan 9

Namun, jangan sekali-kali membicarakan soal peregasan.

Ini perkara sensitif. (SP :29)

Pada kutipan 9 tersebut pronomina penunjuk “ini” merupakan pergantian pengulangan dari kalimat pertama "Namun, jangan sekali-kali membicarakan soal peregasan". Pronomina penunjuk "ini" digunakan di kalimat kedua untuk merujuk pada "jangan sekali-kali membicarakan soal peregasa" pada kalimat sebelumnya. Hubungan tersebut merupakan perujukan endofora katafora. Jadi, dapat dilihat kalimat-kalimat tersebut memiliki keterkaitan yang padu satu sama lain. Kajian ini sesuai dengan teori yang dikemukakan oleh Holliday dan Hasan (dalam Kusuma, 2011: 12).

Kutipan 10

"Melihat keadaan negara sekarang, bisa-bisa Jepang datang lagi!” Ini juga kisah lama. (SP :30)

Pada kutipan 10 pronomina penunjuk "ini" merupakan pergantian pengulangan dari kalimat pertama "Melihat keadaan negara sekarang, bisa-bisa Jepang datang lagi!". Pronomina penunjuk "ini" digunakan di kalimat kedua untuk merujuk pada "Melihat keadaan negara sekarang, bisabisa Jepang datang lagi!" pada kalimat sebelumnya. Hubungan tersebut merupakan perujukan endofora katafora. Jadi, dapat diketahui kalimat-kalimat tersebut memiliki keterkaitan yang padu satu sama lain. Kajian ini sesuai dengan teori yang dikemukakan oleh Holliday dan Hasan (dalam Kusuma, 2011: 12).

\section{Kutipan 11}

Ayah pasti menuntun sepedanya waktu mendaki bukit Selumar, dan tetap menuntunnya ketika menuruni bukit itu sebab terlalu curam. Dia akan melakukan hal yang sama saat mendaki dan menuruni bukit Selinsing. (SP :80)

Pada kutipan 11 frasa "yang sama" pada kalimat kedua merupakan pergantian pengulangan dari frasa "menuntun sepedanya" pada kalimat pertama. Frasa "yang sama" digunakan di kalimat kedua untuk merujuk pada "menuntun sepedanya" pada kalimat sebelumnya. Hubungan tersebut merupakan perujukan endofora katafora. Jadi, dapat diketahu bahwa kalimatkalimat tersebut memiliki keterkaitan yang padu satu sama lain. Kajian ini 
sesuai dengan teori yang dikemukakan oleh Holliday dan Hasan (dalam Kusuma, 2011: 12).

Kutipan 12

Seluruh isi perutku seakan naik mengumpul di ulu hati. Tampak jelas, Arai dan Jimbron mengalami hal yang sama. (SP :100)

Pada kutipan (5) frasa "yang sama" pada kalimat kedua merupakan pergantian pengulangan dari kalimat pertama "Seluruh isi perutku seakan naik mengumpul di ulu hati". Frasa "yang sama" digunakan di kalimat kedua untuk merujuk pada "Seluruh isi perutku seakan naik mengumpul di ulu hati” pada kalimat sebelumnya. Hubungan tersebut merupakan perujukan endofora katafora. Jadi, dapat diketahui bahwa kalimat-kalimat tersebut memiliki keterkaitan yang padu satu sama lain. Kajian ini sesuai dengan teori yang dikemukakan oleh Holliday dan Hasan (dalam Kusuma, 2011: 12).

Kutipan 13

Kami hanya pernah membaca di buku Himpunan Pengetahuan Umum waktu masih SD dulu: Bogor ada di Jawa Barat, Kota Hujan. Hanya itu pengetahuan kami tentang Bogor. (SP :219)

Pada kutipan 13 tersebut pronomina penunjuk "itu" pada kalimat kedua merupakan pengulangan pergantian kalimat "Bogor ada di Jawa Barat, Kota Hujan." pada kalimat pertama. Pronomina penunjuk "itu" digunakan di kalimat kedua untuk merujuk pada "Bogor ada di Jawa Barat, Kota Hujan" pada kalimat sebelumnya. Hubungan tersebut merupakan perujukan endofora katafora. Jadi, dapat diketahui bahwa kalimat-kalimat tersebut memiliki keterkaitan yang padu satu sama lain. Kajian ini sesuai dengan teori yang dikemukakan oleh Holliday dan Hasan (dalam Kusuma, 2011: 12).

\section{SIMPULAN}

Berdasarkan hasil dan pembahasan, dapat disimpulkan bahwa ditemukan jenis kohesi gramatikal referensi dan kohesi gramatikal substitusi dalam novel Sang Pemimpi karya Andrea Hirata sebanyak 137 kutipan. Jenis kohesi gramatikal referensi lebih dominan dibandingkan jenis kohesi gramatikal substitusi, sebagai berikut.

1. Jenis kohesi gramatikal referensi (pengacuan) dalam novel Sang Pemimpi karya Andrea Hirata terdapat sebanyak 130 kutipan, yang terdiri atas kohesi gramatikal referensi endofora anafora sebanyak 122 kutipan, dan kohesi gramatikal referensi endofora katafora sebanyak 8 kutipan.

2. Jenis kohesi gramatikal substitusi (penyulihan) dalam novel Sang Pemimpi karya Andrea Hirata terdapat 7 kutipan, dan ketujuh kutipan tersebut merupakan kohesi gramatikal substitusi endofora anafora.

\section{Saran}

Berdasarkan kesimpulan di atas, terdapat beberapan saran yang dapat disampaikan, sebagai berikut.

1. Dengan hasil penelitin penelitian ini, diharapkan para pembaca dapat menambah kecintaan terhadap karya sastra khususnya karya-karya sastrawan Indonesia.

2. Hasil penelitian ini diharapkan dapat menambah referensi bagi guru bahasa Indonesia dalam pembelajaran bahasa maupun sastra di sekolah.

3. Disarankan kepada peneliti lain di masa yang akan datang agar dapat 
melakukan penelitian yang lebih mendalam mengenai jenis kohesi gramatikal konjungsi dengan lebih baik.

\section{DAFTAR PUSTAKA}

Ahmadi, Ruslam. (2016). Metode Penelitian Kualitatif. Yogyakarta: Ar- Ruzz Media.

Arifin, Zainal. (2010). Metodologi Penelitian Pendidikan Filosofi, Teori dan Aplikasi. Surabaya: Lentera Cendikia.

Chaer, Abdul. (1998). Tata Bahasa Praktis Bahasa Indonesia. Jakarta: PT. Rineka. Cipta. Dewojati. Cahayaningrum.

Endraswara, Suwardi. (2013). Metode Peneliti Sastra, Epitemologi, Model, Teori, dan Aplikasi. Yogyakarta: CAPS (Center for Academic Publising Service).

Hirata, Andrea. (2008). Sang Pemimpi. Jakarta: PT. Bentang Pustaka.

Kusuma, Okke. (2011). Telaah Wacana. Jakarta: The Intercultural Institute.

Pernando, E., \& Rahima, A. (2017). Analisis Kohesi Leksikal dalam Majalah Patriotik LPM Universitas Batanghari Edisi XVI Juli-September Tahun 2016. Aksara: Jurnal Ilmiah Pendidikan Bahasa dan Sastra Indonesia, 1(1), 1-10.

Rofii, Afif. dan Hasibuan, Rizka Rani (2019) Interferensi Bahasa Batak Mandailing dalam Tuturan Berbahasa Indonesia Pada Acara Parpunguan Masyarakat Mandailing Kota Jambi. Aksara. Aksara: Jurnal Ilmiah Pendidikan Bahasa dan Sastra Indonesia Vol. 3 No. 1 April 2019.

Siswantoro, (2010). Metode Penelitian Sastra, Analisis Struktural Puisi. Yogyakarta: Pustaka Pelajaran.
Sugiyono. (2016). Memahami Penelitian Kualitatif. Bandung: Alfabeta. Zaimar, O K S dan Harap, AB. (2009). Telaah Wacana. Jakarta: The Intercultural Institute. 